Chem. Chem. Technol., 2017, Vol. 11, No. 3, pp. 277- 284

Chemistry

\title{
MODIFIED POLYETHERSULFONE MEMBRANES WITH PHOTOCATALYTIC PROPERTIES
}

\author{
Oleh Dzhodzhyk ${ }^{1}$, Iryna Kolesnyk ${ }^{1}$, Victoriia Konovalova1, *, Anatoliy Burban
}

https:

\begin{abstract}
The photocatalityc nanocomposite membranes with tin(IV) oxide nanoparticles were obtained by "layerby-layer" self-assembly. Polyelectrolyte complexes with different nature were analyzed as a binder for nanocatalysts. PEI was used as a positively charged polyelectrolyte, and CMC, sodium alginate, $\kappa$ - or $\mathrm{t}^{-}$ carrageenans were used as negatively charged ones. The presence of $\mathrm{SnO}_{2}$ on the membrane surface was confirmed by a scanning electron microscopy (SEM). Polyelectrolyte complexation was studied by zeta-potential measurement. The photocatalytic activity of the nanocomposite membranes was evaluated in the process of milk nanofiltration. The modification of polyethersulfone membranes with polyelectrolyte layers and $\mathrm{SnO}_{2}$ nanoparticles allowed to produce a highly concentrated retentate and membrane flux remained stable for over $8 \mathrm{~h}$.
\end{abstract}

Keywords: polyethersulfone membrane, tin(IV) oxide, "layer-by-layer" method, milk concentration.

\section{Introduction}

In recent years, the membranes with photocatalytic nanoparticles have attracted a great attention due to their superior characteristics (e.g., antifouling and photocatalytic properties) [1]. Photocatalytic reactions, as a type of advanced oxidation processes, are able to degrade organic and toxic pollutants into simple and harmless compounds. These reactions are catalyzed by the photocatalytic active nanoparticles to generate hydroxyl radicals, which are the strongest oxidants except for fluorine in aqueous solutions [2]. However, some disadvantages of photocatalytic reactors, including a high cost for catalyst and low stability in a long-term run, still need to be resolved.

Immobilization of photocatalyst on membranes has the advantages such as unnecessity of the catalyst separation/recycling; the membrane usage can continue as

\footnotetext{
${ }^{1}$ National University of Kyiv-Mohyla Academy,

2, Skovoroda St., 04655 Kyiv, Ukraine

*v_konovalova@yahoo.com

(C) Dzhodzhyk O., Kolesnyk I., Konovalova V., Burban A., 2017
}

long as the catalyst activity remains high. Also, decomposition of the organic pollutants in the gel layer or filtration cake and the enhancement of hydrophilicity of the catalyst modified membranes may reduce their fouling [3]. Membranes can be purposely modified to improve their hydrophilicity and antifouling ability through planting polar organic functional groups onto membrane surface. The usual approaches consist of surface coating, plasma treatment, surface grafting, and surface blending, etc. [4]. $\mathrm{TiO}_{2}$ particles and polar organic functional groups could be immobilized together onto membrane surface, and thereby the immobilization of catalyst and membrane surface modification occurs simultaneously. Based on above, hydrophilicity and antifouling ability of membrane surface can be enhanced due to minimization of mass transfer resistance between the semi-conductor surface and fluid bulk via the forced transport of reactants by convection [5]. Great variety of materials has been used for the membrane surface modification, such as $\mathrm{TiO}_{2}$ nanotubes [6], $\mathrm{TiO}_{2}$-graphene oxide (GO) [7-9], carbon nanotubes (CNTs) [10-13], etc.

Titanium dioxide $\left(\mathrm{TiO}_{2}\right)$ is the most commonly used material for the fabrication of photocatalytic membranes due to its low cost, non-toxicity and high chemical stability [14]. Application of UV light or hydroxyl radicals, produced by $\mathrm{TiO}_{2}$, may damage polymer membranes. Early development of photocatalytic membranes has been focusing on flat sheet membranes made from polyacrylonitrile (PAN), which were stable against UV light over $24 \mathrm{~h}$ period of irradiation [15]. Nevertheless, Chin et al. [16] concluded that polytetrafluoroethylene (PTFE) and hydrophobic polyvinylidene fluoride (PVDF) were the better choice for the photocatalytic application, based on UV and oxidative screening tests. Unlike PAN, it is possible to use PVDF and PTFE-based polymers for 10 day exposure.

Conducting polymers have been employed to improve the photocatalytic activities of semiconductor oxide photocatalysts, including $\mathrm{ZnO}, \mathrm{SnO}_{2}$, and $\mathrm{TiO}_{2}$ [17]. These polymers have demonstrated a strong photoresponse in the visible range as well as satisfactory photogenerated hole transportation ability. 
In our work, the photocatalytic membranes were developed by immobilization of $\mathrm{SnO}_{2}$ nanoparticles on the polyethersulfone ultrafiltration membranes with "layerby-layer" (LbL) technic. LbL assembly exploited the charge of polyelectrolytes to adsorb the suspended catalytic nanoparticles on a surface. This process included two steps: a) deposition of polyelectrolytes (PE) on the surface, and then b) exposing the polyelectrolyte-modified surface to a nanoparticle suspension to enable particle adhesion thereto. We have researched the effect of $\mathrm{SnO}_{2}$ nanocomposites on the membrane performance, morphology, and antifouling properties during milk nanofiltration without application of UV irradiation.

\section{Experimental}

\subsection{M aterials}

All chemicals used were of reagent grade. Sodium alginate, polyethylenimine (PEI), $\kappa$ - and $\mathrm{t}$-carrageenans were purchased from Fluka (Japan) and used without further purification. Poly(sodium 4-styrenesulfonate) (PSS), sodium carboxymethyl cellulose (CMC) were purchased from Sigma Aldrich (USA). Tin(IV) oxide nanoparticles $\left(\mathrm{SnO}_{2}\right.$ particles size $\left.<100 \mathrm{~nm}\right)$ were obtained from Sigma Aldrich (USA). Commercial polyethersulfone membranes UF-PES-020H with cut-off $20 \mathrm{kDa}$ (Microdyn Nadir, Germany) were used for modification. Reagent solutions were prepared by using the deionized water as a solvent.

\subsection{M embrane M odification by "Layer-by-Layer" M ethod}

Polyelectrolyte solutions were alternately deposited on the membrane surface for $15 \mathrm{~min}$ each with a water rinse between the layers for membrane modification. Sodium polystyrene sulfonate $\left(0.02 \mathrm{~mol} \cdot \mathrm{l}^{-1}\right)$ was used as the first layer since it adsorbs well on a polyethersulfone surface by hydrophobic interactions [18]. Next layers were assembled using PEI (MW $750 \mathrm{kDa}$ ) as a positively charged polyelectrolyte and CMC, sodium alginate, $\kappa$ - or 1-carrageenans as negatively charged ones (Fig. 1). They adsorbed on the previous layer via electrostatic interactions and van der Waals forces [19]. The sonicated $\mathrm{SnO}_{2}$ nanoparticles were used as the top layer because they had a negative charge at $\mathrm{pH} 6.5$ and adsorbed on PEI layer [20], thus resulting in 3.5 layers.<smiles></smiles>

a)

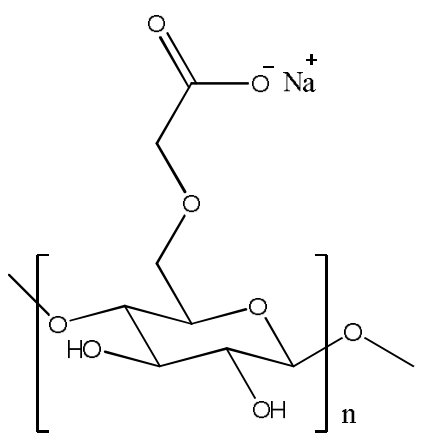

d)<smiles>CC(C)(C)CCNC(C)(C)C</smiles>

b)

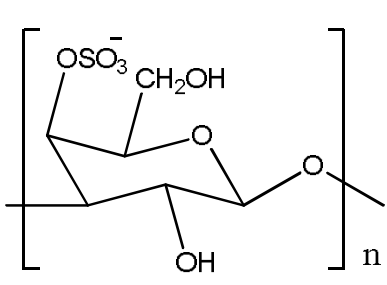

e)

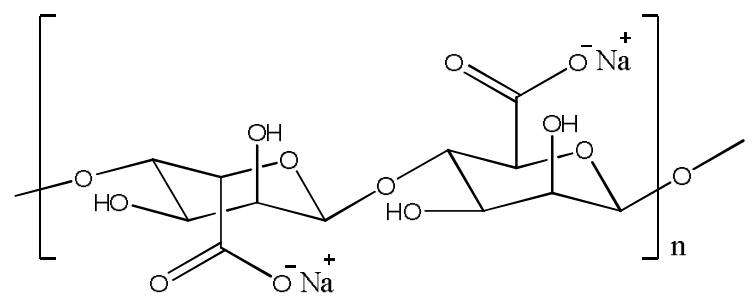

c)

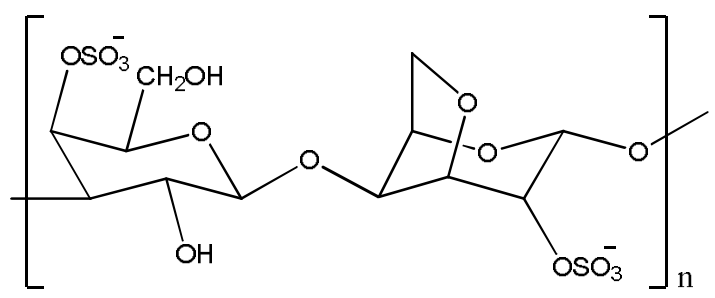

f)

Fig. 1. Repeating units of the polyelectrolytes used for multilayering: a) PSS (strong polyanion); b) PEI (weak polycation); c) sodium alginate (weak polyanion); d) sodium carboxymethyl cellulose (weak polyanion); e) $\kappa$-carrageenan (strong polyanion); 


\subsection{SEM Analysis}

Microscopic images were recorded using field emission scanning electron microscope JEOL JSM 6700F (Japan) under the condition of low vacuum (accelerating voltage $10 \mathrm{kV}$, magnification from $\times 1000$ to $\times 100000$ ) applied to samples with deposition of a thin film of platinum.

\section{4. Ђ-Potential M easurements}

The measurements of membrane $\zeta$-potential were made using Electrokinetic Analyzer (Anton Paar GmbH, Austria) at room temperature at $\mathrm{pH} 6.5$ in $10^{-3} \mathrm{M}$ solution of $\mathrm{KCl}$. The EKA software program calculated $\zeta$-potential of a membrane surface through the streaming potential data using the Helmholtz-Smoluchowski equation [21]:

$$
\zeta=\frac{d U}{d p} \cdot \frac{\eta}{\varepsilon \varepsilon_{0}} \cdot \frac{L}{A} \cdot \frac{1}{R}
$$

where $\zeta$ is the apparent zeta potential of membrane; $d U / d p$ is the slope of streaming potential versus pressure; $\eta$ is the electrolyte viscosity; $\varepsilon$ is the dielectric constant of electrolyte; $\varepsilon_{0}$ is the vacuum permittivity; $L$ is the length of the streaming channel; $A$ is the cross-section of the streaming channel; $R$ is the resistance inside the measurement cell.

\subsection{Filtration Studies}

A dead-end stirred cell (Amicon-8050, MA) with a transparent plastic cell and effective membrane area of $13.4 \mathrm{~cm}^{3}$ was used for the filtration experiments. All experiments were carried out at room temperature and in daylight. Additional UV irradiation was not applied. The permeation flux of the membranes was determined by the measuring the permeate volume during a certain period of time. Rejection was calculated by the following equation:

$$
R=1-\frac{C_{p}}{C_{m}}
$$

where $C_{p}$ is the permeate concentration and $C_{m}$ is the feed concentration.

\subsection{Permeate and Retentate Characteri- zation after Milk N anofiltration}

Amount of total proteins and casein was determined by the titration method. 10-12 drops of $1 \%$ alcohol solution of phenolphthalein were added to $10 \mathrm{ml}$ of milk, and the solution was titrated by $0.1 \mathrm{~N}$ solution of $\mathrm{NaOH}$ until changing colour to slightly pink, which did not disappear after shaking. Then the volume of titrant was fixed. After that $2 \mathrm{ml}$ of $37 \%$ solution of formalin, neutralized with alkali, was added to the sample and titration lasted to the moment of colour change. At this moment the volume of titrant was also fixed. In order to determine the total protein content, the amount of $\mathrm{NaOH}$ after formalin adding was multiplied by the factor of 1.92 , and for determination of the casein content the one was multiplied by a factor of 1.51 [22].

Lactose content was determined refractometrically in the lactoserum after milk coagulation adding $4 \%$ calcium chloride.

The total solids were determined by the gravimetric method, drying milk at $393 \mathrm{~K}$ to a constant weight.

For measuring coagulation time, $10 \mathrm{ml}$ of milk was heated to $310 \mathrm{~K}$ on a water bath and $2 \mathrm{ml}$ of the rennet was added. The time, at which first nuclei appeared, was recorded.

\section{Results and Discussion}

\subsection{Modification of Polyethersulfone Membranes by "Layer-by-Layer" Method}

Modification of polyethersulfone membranes was carried out using the "layer-by-layer" method because of its simplicity and effectiveness. Adsorption of polyelectrolyte layers was evaluated indirectly by changing the membrane water fluxes at applied pressure of $300 \mathrm{kPa}$. Fig. 2 shows that the largest decline of membranes permeability was observed after adsorption of the first bilayer PEI/polysaccharide. And only a slight decrease of membrane water flux has been observed with further modification. It should be noted that membrane modification with $\mathrm{SnO}_{2}$ nanoparticles resulted in its surface hydrophilization as compared to the unmodified polyethersulfone membranes. This effect will reduce the adsorption of proteins and fats on membrane surface during milk nanofiltration.

Layers adsorption was confirmed by measuring zeta potential of membrane surface. The unmodified polyethersulfone membranes had negative zeta potential values. The alternation of zeta potential value due to charge compensation indicated the successful deposition of each weak polyelectrolyte onto the surface (Figs. 3a, b). As can be seen in Figs. 3c, $d$ for polysaccharides with sulfonic groups only the first layer caused a negative charge of membrane surface, and further modification did not provoke zeta potential inversion. This fact can be explained by the formation of polyelectrolyte complexes with different structure. Therefore, the interaction of weak polyelectrolytes as PEI with CMC or sodium alginate produces complexes, which can be described by the scrambled egg model. In this case there is a large number of free chains that can interact with further polyelectrolyte 
and give charge for membrane surface [23]. Weak (PEI) and strong polyelectrolytes ( $\kappa$ - and $\mathrm{t}$-carrageenans) form the equimolar ladder-like structures [24], in which most of the charges are compensated. So, they cannot adsorb next
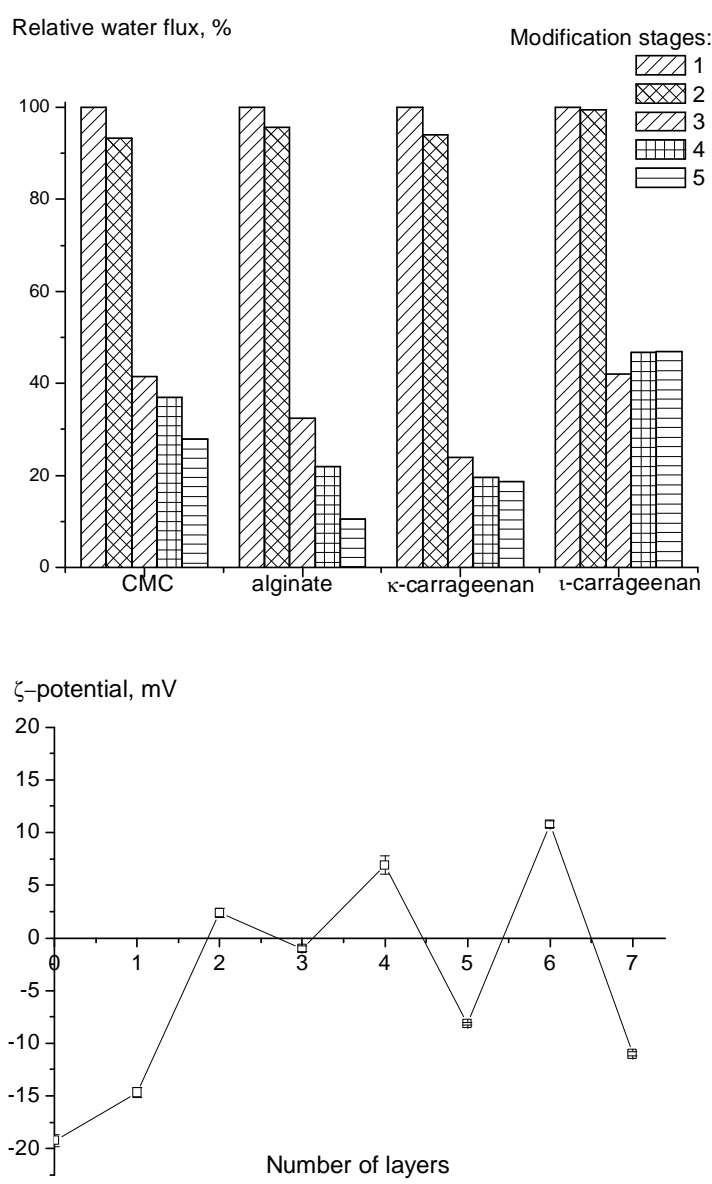

a)

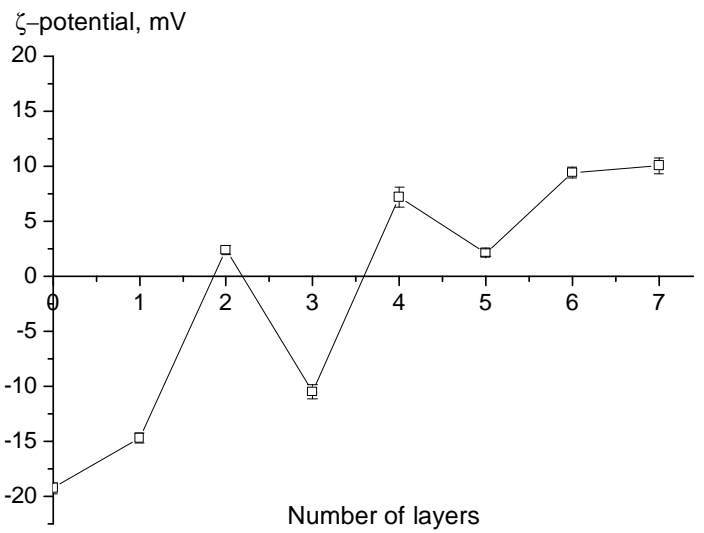

c) polyelectrolyte due to incapability of polymer chains to undergo conformation reorganization [25]. Therefore, a small amount of $\mathrm{SnO}_{2}$ nanoparticles on the surface of such membranes can be assumed.
Fig. 2. Permeability of membranes,

modified by polyelectrolyte layers $\mathrm{PEI} /$ polysaccharide, at different stages of modification: the unmodified membrane (1); deposition of the PSS layer (2); deposition of the first bilayer (3); deposition of the second bilayer (4) and deposition of PEI layer and $\mathrm{SnO}_{2}$ nanoparticles (5)

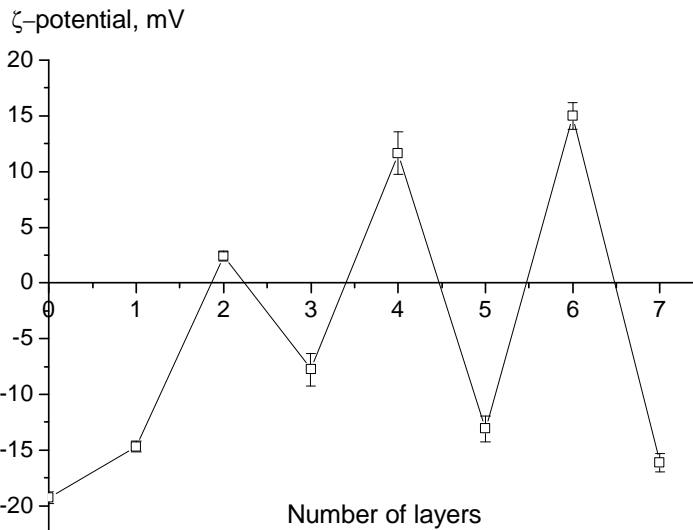

b)

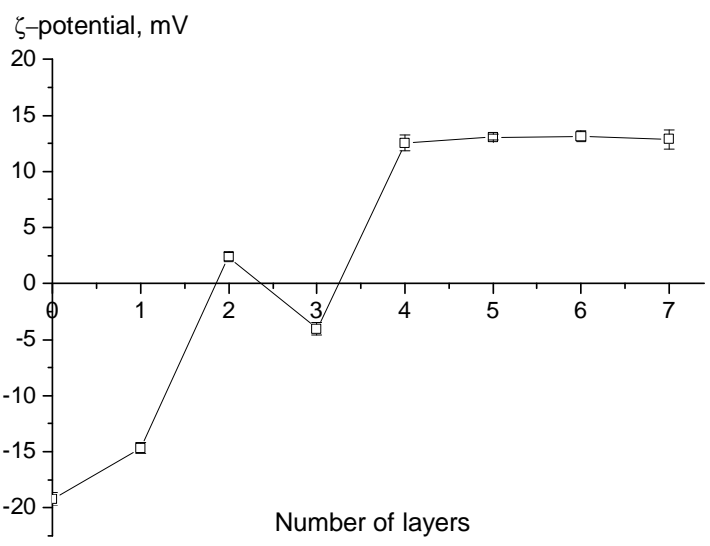

d)

Fig. 3. Zeta potential of membranes at different stages of modification by different PEI/polysaccharide complexes: a) $\mathrm{CMC}$; b) sodium alginate; c) $\kappa$-carrageenan; d) 1 -carrageenan. Layers: 0 - the unmodified membrane; 1 - PSS; 2 -PEI; 3 - polysaccharide; 4 - PEI; 5 - polysaccharide; 6 - PEI; 7 - $\mathrm{SnO}_{2}$ nanoparticles. 


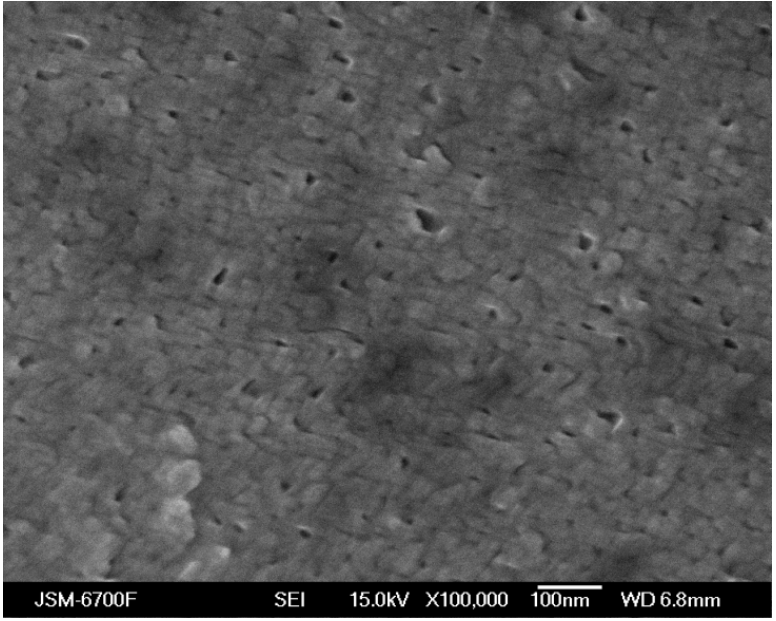

a)

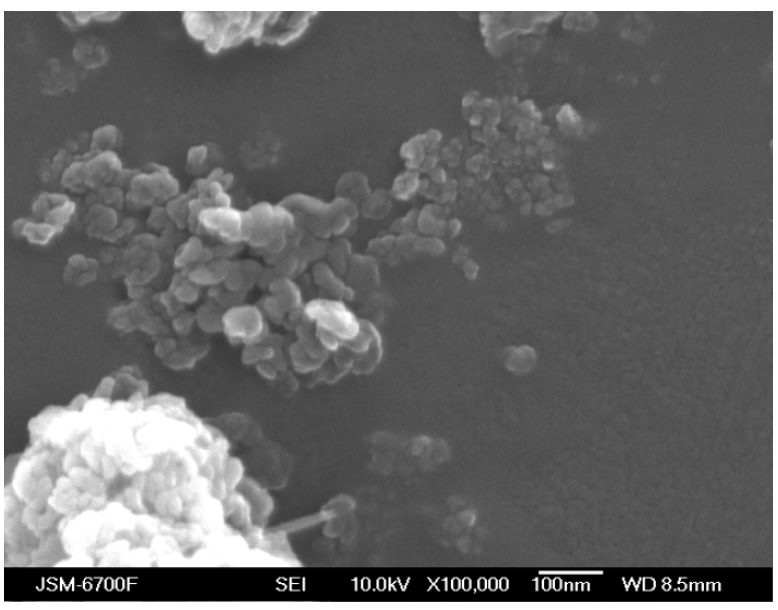

c)

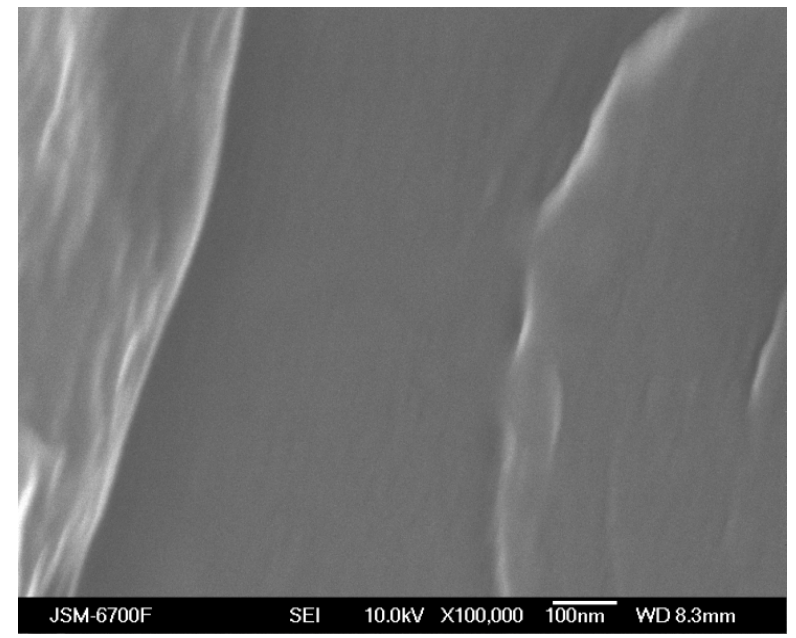

b)

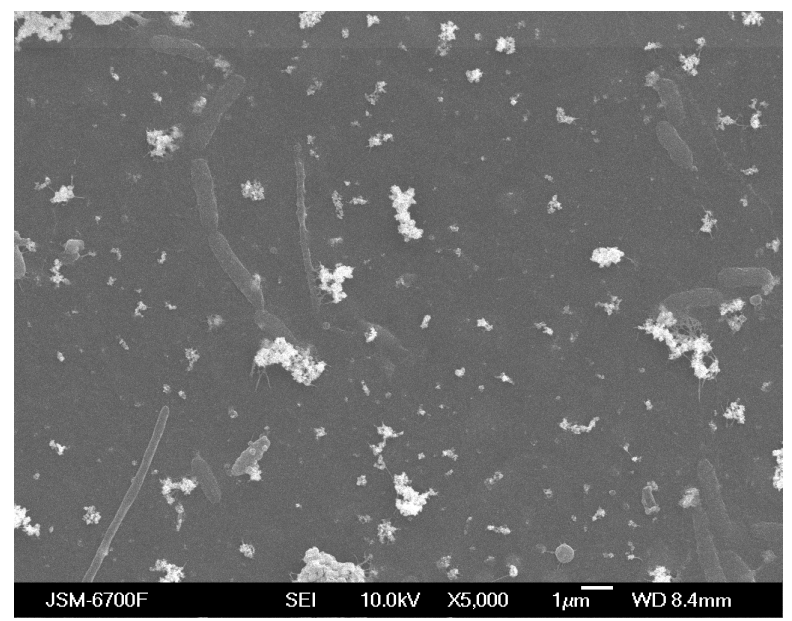

d)

Fig. 4. SEM images of membrane surface: the unmodified membrane (a); membrane, modified by polyelectrolyte PEI/CMC layers (b); membrane, modified by polyelectrolyte PEI/CMC layers and $\mathrm{SnO}_{2}$ nanoparticles (c, d)

Fig. 4 shows the SEM images of the membranes before and after modification by the PEI/CMC complexes. It was confirmed that polyelectrolyte layers smoothly cover the membrane surface (Fig. 4b). It means that the $\mathrm{PEI} /$ polysaccharides coating was evenly deposited on the membrane surface, which was beneficial for the following modification by nanoparticles. At high magnification it can be seen that $\mathrm{SnO}_{2}$ nanoparticles were well dispersed on the membrane surface (Fig. 4c). But somewhere its agglomerates can be found (Fig. 4d). The average size of $\mathrm{SnO}_{2}$ nanoparticles was confirmed by SEM to be approximately $40 \mathrm{~nm}$.

\subsection{Calcium Rejection by PEI/ Polysaccharide Membranes}

The high calcium content in the concentrated milk is an important parameter for its coagulation and buffering capacity that affects cheese-making aspects such as rheology, water holding capacity, lactic acid production, etc. [26, 27]. For this purpose, we examined the ability of membranes modified by polyelectrolyte layers to reject calcium. The feed solution contained $1 \mathrm{~g} / \mathrm{l}$ of $\mathrm{Ca}^{2+}$. So, for unmodified membrane there was no calcium rejection due to the large pore size, and for modified membranes the calcium rejection was $30-40 \%$ and it eventually decreased (Fig. 5). For membranes modified by polyelectrolyte complexes of $\mathrm{PEI} /$ alginate a rapid decline of selectivity was observed, which can be explained by alginate cross-linking with $\mathrm{Ca}^{2+}$ ions, and consequently reducing the surface charge and electrostatic effect [28]. Thus, some amount of calcium will be contained in retentate during milk concentration. 


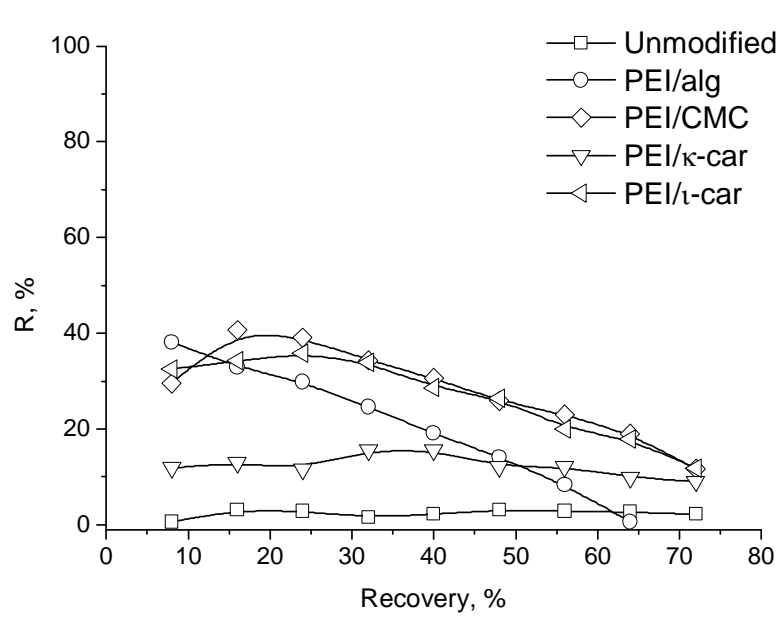

Fig. 5. Effect of membrane modification by different polyelectrolyte complexes on calcium rejection (concentration of $\mathrm{CaCl}_{2} 1.0 \mathrm{~g} / \mathrm{l}$, operating pressure $300 \mathrm{kPa}$ )

\subsection{Milk Concentration by Membranes with Photocatalytic Properties}

Milk nanofiltration is always accompanied by the phenomenon of concentration polarization, since milk has a high content of proteins and fats that accumulate in the boundary layer. In this manner the membrane flux significantly decreases [29-32]. Occurrence of the concentration polarization in certain range of pressures can be evaluated by dependence of flux on the applied pressure (Fig. 6). Fig. 6 shows that the concentration polarization in this pressure range did not affect the flux through membranes modified by layers of weak polyelectrolytes - PEI/CMC and PEI/alginate. This effect can be explained by photocatalytic properties of $\mathrm{SnO}_{2}$ nanoparticles adsorbed by loose polyelectrolyte complexes. They decompose proteins and fats in low molecular weight fragments, which can pass through the membrane and do not adsorb on its surface [33]. For the membranes, modified by layers of PEI and polysaccharides with sulfonic groups $(\kappa-$ and $t-$ carrageenans), the flux increase with the applied pressure raising was not observed, confirming the absence or small amount of nanoparticles with photocatalytic properties on the membrane surfaces.

Further experiments were carried out with membranes modified by polyelectrolyte layers of PEI and polysaccharides with carboxylic groups. Membrane flux stability during milk nanofiltration was studied. As can be seen in Fig. 7, a significant decrease in the permeability of

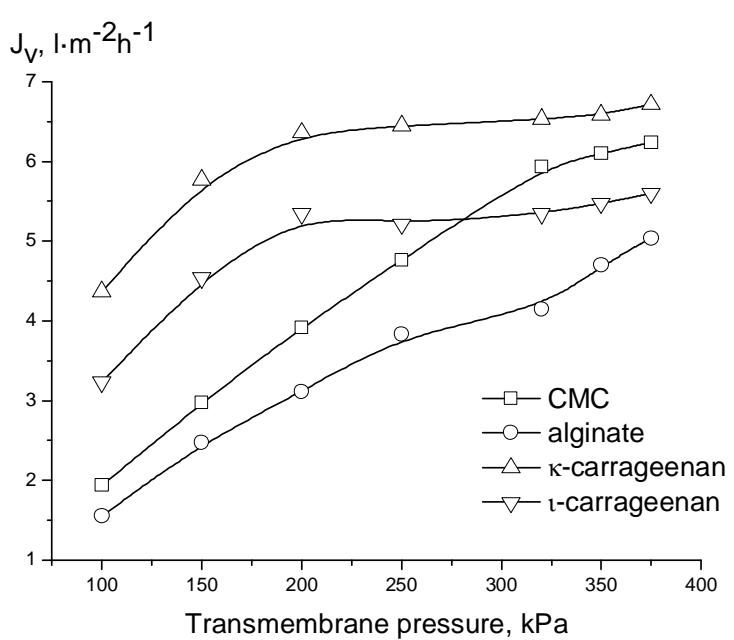

Fig. 6. The influence of the applied pressure on the flux during milk nanofiltration on membranes, modified by different polyelectrolyte layers and $\mathrm{SnO}_{2}$ nanoparticles.

membranes modified only by polyelectrolyte layers without $\mathrm{SnO}_{2}$ nanoparticles, was observed. Whereas, for membranes with tin(IV) oxide nanoparticles, adsorbed on its surface, permeability remained stable for over $8 \mathrm{~h}$.

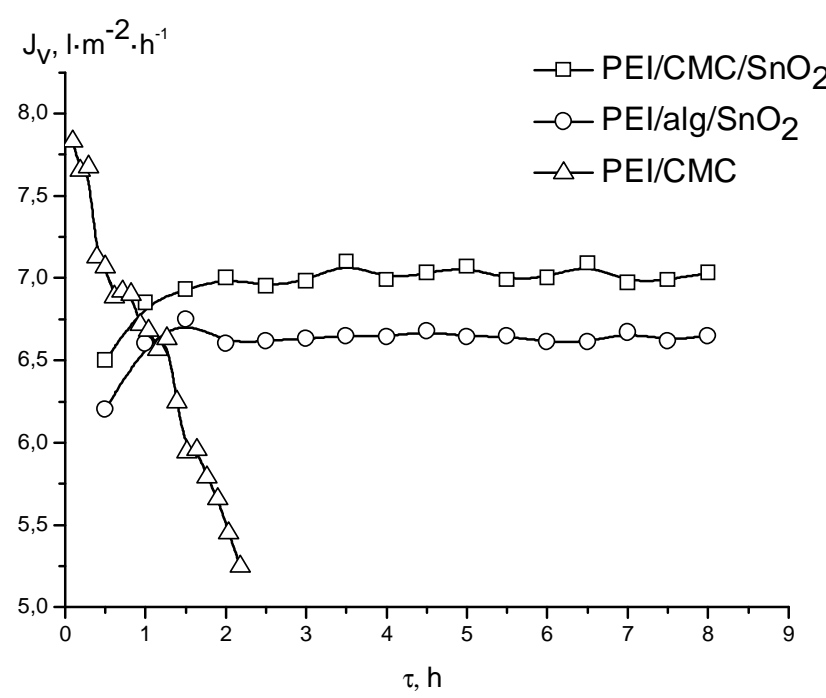

Fig. 7. Permeability of membranes during milk filtration

A threefold milk concentration on modified membranes was performed. The quality of concentration was evaluated based on such parameters as total protein, casein, lactose amount, total solids and time of coagulation. The mean composition of milk, retentate and permeate for each membrane is shown in the Table. 
Composition of feed, retentate and permeate

\begin{tabular}{|c|c|c|c|c|c|}
\hline \multirow[t]{2}{*}{ Characteristics } & \multirow{2}{*}{$\begin{array}{l}\text { Milk TM "Na } \\
\text { zdorovja", } 1 \%\end{array}$} & \multicolumn{2}{|c|}{$\begin{array}{c}\text { Membrane, modified by PEI/CMC } \\
\text { and } \mathrm{SnO}_{2}\end{array}$} & \multicolumn{2}{|c|}{$\begin{array}{c}\text { Membrane, modified by PEI/alginate } \\
\text { and } \mathrm{SnO}_{2}\end{array}$} \\
\hline & & Retentate & Permeate & Retentate & Permeate \\
\hline Total solids, \% & 98.0 & 193.40 & 23.40 & 239.00 & 48.20 \\
\hline Lactose, $\%$ & 6.77 & - & 4.54 & - & 5.11 \\
\hline Total protein, $\%$ & 5.42 & 11.67 & 0.39 & 12.80 & 0.22 \\
\hline Casein, \% & 3.86 & 8.59 & 0.28 & 8.80 & 0.28 \\
\hline Time of coagulation, $\mathrm{s}$ & 200 & 20 & - & 40 & - \\
\hline
\end{tabular}

As compared with skim milk, the concentration of all retentate components increased, in particular, total solids rose by $1.5-2.0$ times. We can also notice that only a twofold concentration of protein was observed, which confirms the photocatalytic activity of tin oxide nanoparticles on membrane surface that cleave proteins to low molecular weight fragments, which was approved by PAGE. Analysis of retentate by electrophoresis did not show the difference between protein molecular weight distribution of skim milk and that one of retentate. Therefore, protein cleavage occurred only in the boundary layer, but not in the bulk. The conclusion can also be made based on the obtained results that lactose rejection occurs at $30 \%$. The use of membranes modified by polyelectrolyte layers of PEI/alginate provides higher total solids, lactose and protein amount in retentate. When evaluating coagulation ability, it can also be determined that the milk concentration significantly accelerated the nucleation while rennet adding from $200 \mathrm{~s}$ for milk to 20 $40 \mathrm{~s}$ for retentate. For this reason, modification of polyethersulfone membranes by polyelectrolyte layers and $\mathrm{SnO}_{2}$ nanoparticles allows to produce the highly concentrated retentate with good potential for cheese manufacture.

\section{Conclusions}

This paper reports the method of immobilization of $\mathrm{SnO}_{2}$ nanoparticles on polyethersulfone membrane to render them photocatalytic properties. $\mathrm{SnO}_{2}$ nanoparticles were immobilized on the membrane surface by $\mathrm{LbL}$ method. PEI was used as a positively charged polyelectrolyte and $\mathrm{CMC}$, sodium alginate, $\kappa-$ or $\mathbf{t}^{-}$ carrageenans as negatively charged ones. The top layer was $\mathrm{SnO}_{2}$ nanoparticles, which had a negative charge at pH 6.5 and are adsorbed on PEI layer. Zeta-potential measurements demonstrated that during the modification of membrane surface its charge had changed. The alternation of zeta potential value due to charge compensation indicated the successful deposition of weak polyelectrolytes onto the surface. The interaction between the weak polyelectrolytes as PEI and CMC or sodium alginate provides complexes, which can be described by the scrambled egg model. Weak (PEI) and strong polyelectrolytes ( $\kappa$ - and $\mathrm{l}$-carrageenans) form the equimolar ladder-like structures, in which most of the charges are compensated. Therefore, the complexes of PEI and CMC or sodium alginate were chosen as the most suitable for $\mathrm{SnO}_{2}$ nanoparticles immobilization.

The use of membranes with immobilized $\mathrm{SnO}_{2}$ nanoparticles for milk concentration during nanofiltration was discussed in terms of concentration polarization effect. It was shown that the nanoparticles layer on the membrane surface prevented rapid increase of the concentration in the boundary layer due to the photocatalytic decomposition. Permeate flux of milk nanofiltration remained stable for over $8 \mathrm{~h}$. The modification of polyethersulfone membranes by polyelectrolyte layers and $\mathrm{SnO}_{2}$ nanoparticles allowed producing a highly concentrated retentate with good potential for cheese manufacturing.

\section{References}

[1] Kim J., Van der Bruggen B.: Environ. Pollut. 2010, 158, 2335. https://doi.org/10.1016/j.envpol.2010.03.024

[2] Zhang W., Ding L., Luo J. et al.: Chem. Eng. J., 2016, 302, 446. https://doi.org/10.1016/j.cej.2016.05.071

[3] Mozia S.: Sep. Purif. Technol., 2010, 73, 71. https://doi.org/10.1016/j.seppur.2010.03.021

[4] Zhang W., Luo J., Ding L. et al.: Ind. Eng. Chem. Res., 2015, 54, 2843. https://doi.org/10.1021/ie504848m

[5] Mendret J., Hatat-Fraile M., Rivallin M. et al.: Sep. Purif. Technol., 2013, 111, 9. https://doi.org/10.1016/j.seppur.2013.03.030 [6] Wu X., Scott K.: Fuel Sells, 2013, 13, 1138. https://doi.org/10.1002/fuce.201200040

[7] Safarpour M., Khataee A., Vatanpour V.: Ind. Eng. Chem. Res., 2014, 53, 13370. https://doi.org/10.1021/ie502407g

[8] Jiang Y., Wang W.-N., Liu D. et al.: Environ. Sci. Technol., 2015, 49, 6846. https://doi.org/10.1021/acs.est.5b00904

[9] Hu M., Zheng S., Mi B.: Environ. Sci. Technol., 2016, 50, 685. https://doi.org/10.1021/acs.est.5b03916

[10] Zhao H., Qui S., Wu L. et al.: J. Membr. Sci., 2014, 450, 249. https://doi.org/10.1016/j.memsci.2013.09.014

[11] Vatanpour V., Madaeni S., Moradian R. et al.: Sep. Purif. Technol., 2012, 90, 69. https://doi.org/10.1016/j.seppur.2012.02.014 [12] Amini M., Jahanshahi M., Rahimpour A.: J. Membr. Sci., 2013, 435, 233. https://doi.org/10.1016/j.memsci.2013.01.041

[13] Vatanpour V., Esmaeili M., Farahani M.: J. Membr. Sci., 2014, 466, 70. https://doi.org/10.1016/j.memsci.2014.04.031 
[14] Leong S., Razmjou A., Wang K. et al.: J. Membr. Sci., 2014, 472, 167. https://doi.org/10.1016/j.memsci.2014.08.016

[15] Molinari R., Mungari M., Drioli E. et al.: Catal. Today, 2000, 55, 71. https://doi.org/10.1016/S0920-5861(99)00227-8

[16] Chin S., Chiang K., Fane A.: J. Membr. Sci., 2006, 275, 202. https://doi.org/10.1016/j.memsci.2005.09.033

[17] Man H., Li C., Yin J. et al.: Mater. Lett., 2016, 168, 103. https://doi.org/10.1016/j.matlet.2016.01.041

[18] Dotzauer D.M., Dai J., Sun L. et al.: Nano Lett., 2006, 6, 2268. https://doi.org/10.1021/nl061700q

[19] Diagne F., Malaisamy R., Boddie V. et al.: Environ. Sci. Technol., 2012, 46, 4025. https://doi.org/10.1021/es203945v

[20] Aziza S., Amirnordinb S., Rahmanc H. et al.: Adv. Mater. Res., 2013, 795, 334

[21] Salgin S., Salgin U., Soyer N.: Int. J. Electrochem. Sci., 2013, 8, 4073.

[22] www.gosthelp.ru/gost/gost45546.html

[23] Thnemann A., Mller M., Dautzenberg H. et al.: Adv. Polym. Sci., 2004, 166, 113. https://doi.org/10.1007/b11350

[24] Tsuchida E.: Pure Appl. Chem., 1994, 31, 1.

[25] Chatterjee S., Salaun F., Campagne C.: Pharmaceutics, 2014, 6, 281. https://doi.org/10.3390/pharmaceutics6020281

[26] Nelson B., Barbano D.: J. Dairy Sci., 2005, 88, 1891. https://doi.org/10.3168/jds.S0022-0302(05)72865-4

[27] Brandsma R., Rizvi S.: J. Dairy Sci., 1999, 82, 2063. https://doi.org/10.3168/jds.S0022-0302(99)75447-0

[28] Chen X., Wang D., Wang W. et al.: Desalin. Water Treat., 2011, 30, 146. https://doi.org/10.5004/dwt.2011.1941

[29] Madaeni S., Rahimpour A.: Polym. Adv. Technol., 2005, 16, 717. https://doi.org/10.1002/pat.647

[30] Atra R., Vatai G., Bekassy-Molnar E. et al.: J. Food Eng., 2005, 67, 325. https://doi.org/10.1016/j.jfoodeng.2004.04.035

[31] Razavi S., Mortazavi S., Mousavi S.: J. Water Soil Sci., 2006, 10, 191.
[32] Limsawat P.: Asian J. Food Agro-Ind., 2010, 3, 236.

[33] Kolesnyk I., Dzhodzhyk O. et al.: Ukr.-Polish Conf. "Membrane and sorption processes and technologies", Ukraine, Kyiv 2014, 100.

Received: N ovember 07, 2016 / November 18, 2016 / Accepted: J anuary 30, 2017

\section{МОДИФІКОВАНІ ПОЛІЕТЕРСУЛЬФОНОВІ МЕМБРАНИ З ФОТОКАТАЛІТИЧНИМИ ВЛАСТИВОСТЯМИ}

Анотація. За допомогою електростатичної взаємодії поліелектролітів методом «layer-by-layer» одержані фотокаталітичні мембрани з наночастинками станум(IV) оксиду. Для іммобілізаиії нанокаталізатору використовувалися поліелектролітні комплекси різної природи. Як позитивно заряджений поліелектроліт використовувався поліетиленімін, як негативно заряджені - натрій карбоксиметилцелюлоза, натрій альгінат, к- чи l-карагінан. Наявність $\mathrm{SnO}_{2}$ на поверхні мембран підтверджена сканувальною електронною мікроскопією (СЕМ). Утворення комплексів поліелектролітів підтверджено за допомогою дзета-потениіометрії. Фотокаталітична активність нанокомпозитних мембран оцінена у прочесі нанофільтрації молока. Модифікування поліетерсульфонових мембран поліелектролітними шарами і наночастинками $\mathrm{SnO}_{2}$ дало можливість отримати висококонцентрований ретентат $i$ досягти стабільної продуктивності мембран більше 8 годин.

Ключові слова: поліетерсульфонова мембрана, станум(IV) оксид, метод «layer-by-layer», конщентрування молока. 